\title{
The Impact of Currency Risk on the Value of Firms in Emerging Countries
}

\section{Ilia Kuchin}

Junior Research Fellow

ORCID

E-mail: ikuchin@hse.ru

Institute for Statistical Studies and Economics of Knowledge, National Research University Higher School of Economics, Moscow, Russia

\section{Mariia Elkina}

Graduate student

$\underline{\text { ORCID }}$

E-mail: mchernotalova@hse.ru

Faculty of Economic Sciences, National Research University Higher School of Economics, Moscow, Russia

\section{Yury Dranev}

$\mathrm{PhD}$, Leading Research Fellow

ORCID

E-mail: ydranev@hse.ru

Faculty of Economic Sciences, National Research University Higher School of Economics, Moscow, Russia

Journal of Corporate Finance Research, Vol. 13, No. 1, pp. 7-27 (2019)

DOI: https://doi.org/10.17323/j.jcfr.2073-0438.13.1.2019.7-27

Received 11 January 2019 | Peer-reviewed 2 February 2019 | Accepted 5 March 2019 


\section{The Impact of Currency Risk on the Value of Firms in Emerging Countries}

\section{Abstract}

This study is dedicated to estimating the impact of currency risk on the cost of equity in Brazil, Russia, India and South Africa. Our contribution to the literature is that we have obtained evidence on the pricing of exchange rate risk in developing countries, which at the time of writing is quite scarce. This scarcity is one motivation for our research, which is dedicated to BRICS capital markets, though with the Chinese stock market excluded since it is heavily regulated. The aim of this research is to determine whether in emerging countries stock markets currency risk is a significant factor that influences the cost of equity capital in a company.

Changes in the value of exchange rates can impact the cash flows of a firm and its exposure to risk, and hence, the value of the company. In our research we will discuss the influence of exchange rate movements on the value of firms through their impact on the cost of equity. Specifically, we investigate whether companies that report substantial currency gains or losses have to pay a higher required rate of return on equity. Furthermore, in this study we make an attempt to estimate currency risk premia for exposure to appreciation and depreciation of currency separately, and try to identify possible differences.

For each country, three analytical models that extend the Fama-French Three Factor Model (by incorporating currency risk) are estimated. We use an equal-weighted portfolio approach to identify currency risk factors. These factors are estimated either by using information about the ratio of currency gains to sales, or the magnitude of covariation between equity returns and exchange rate changes. In the second case appreciation and depreciation of domestic currency against the US dollar is considered separately.

The results indicate that in Russia, firms which report substantial currency losses pay a positive risk premium, while in Brazil, India and South Africa companies with significantly positive or negative currency gains pay a lower required return on equity than firms with almost zero currency gains. Finally, we attempt to explain the estimation results using a sectoral breakdown of product exports for each country of the data sample.

Keywords: exchange rate exposure, cost of equity, currency markets, stock returns, emerging markets JEL classification: G12, G32 


\section{Introduction}

The impact of upward or downward exchange rate movements on stock market performance (and vice versa) has important implications in terms of risk management, trading and hedging strategies for international portfolios. Changes in the value of currency influence stock prices since they alter the cash flows of domestic companies and affect their competitiveness on international markets. The stock market also impacts the exchange rate market due to the fact that changes in stock prices alter the attractiveness of domestic assets and consequently leads to inflows or outflows of capital. For this reason, it is extremely important for international investors, top management of companies, and policy makers to understand the relationship between stock prices and exchange rates. Moreover, recently, currencies of developing countries experienced a period of great pressure. During 2014-2015 the Russian ruble depreciated against the US dollar by $118 \%$, the Brazilian Real by $66 \%$, and the South African Rand by $43 \%$. We can see that fluctuations in the nominal exchange rate (Figure 1) in Russia are similar to those in Brazil and South Africa but different to India. According to Morgan Stanley, the currencies of Brazil, India, Indonesia, South Africa and Turkey were the five most fragile currencies as of August 2013 [1]. Two years later the list was extended: the Brazilian Real, Colombian Peso, Chilean Peso, South African Rand, Peruvian Sol, South Korean Won, Thai Baht, Russian Ruble, Singapore Dollar, and Taiwan Dollar were named the "fragile ten" [2]. Still, it is not obvious in which cases this depreciation represented a significant currency risk. Indeed, only unexpected currency value changes can be referred to as currency risks. In addition, in certain countries, currency risk might not be priced. For example, Morgan Stanley analysts believe that securities in South Africa and India were not substantially harmed by currency depreciation as of December of 2013 [3].
The first question that arises in this regard is what kind of currency movements should be considered to be exchange rate risk. Adler and Dumas point out that a substantial depreciation or appreciation of a currency does not, by itself, represent a risk. Exchange rate risk is present only if currency changes are unexpected. The second question is how much exchange risk does a firm bear, i.e. how exposed to currency risk is a specific firm? Adler and Dumas define currency exposure as "sensitivity to the future, real domestic currency (market) value of any physical or financial or financial asset to random variations in the future domestic purchasing powers of these foreign currencies" [4].

What determines a firm's exchange rate exposure? First, companies with international operations are exposed because currency movements affect their cash flows. Bodnar and Martson mention three types of such operations: exporting goods, using imported materials in the production of goods, and producing goods abroad. Using a simple model, they show that a degree of currency risk exposure is different for exporters, importers and international companies. Pure exporters are the most exposed, while pure importers are exposed less because expenses are usually lower than revenue. International firms are the least exposed companies due to the fact that they both produce and sell abroad. Consequently, they are operationally hedged [5].

Bodnar, Dumas and Martson demonstrate a less obvious channel through which fluctuations in exchange rates impact an exporting firm: they influence an exporter's competitiveness, as compared to companies who both produce and sell abroad. Consequently, the cash flows of an exporting company change not only because of the conversion effect, but also due to changes in its market share and profit margin. The latter effects happen because the depreciation or appreciation of a currency affects prices only partially [6].

Figure 1. Nominal exchange rate in Russia, Brazil, India and South Africa (US dollar) ${ }^{1}$

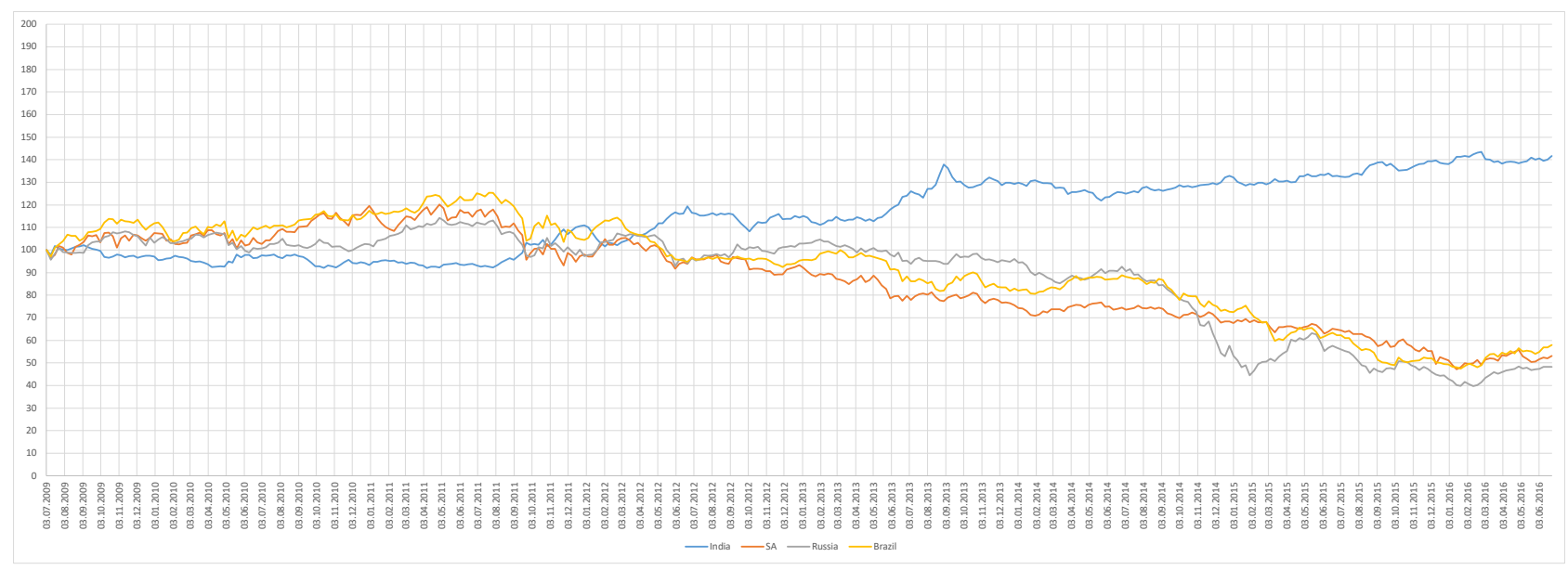

\footnotetext{
${ }^{1}$ Note: $03.07 .2009=100$.
}

Source: Thomson Reuters Datastream. 
Companies which operate in domestic markets only are also exposed to exchange rate risk. Aggarwal and Harper point out that domestic firms indirectly compete with firms which work abroad. They also compete with international companies directly. Furthermore, changes in the value of foreign currencies impact foreign demand for domestic goods. As a result, the domestic prices of these goods change [7].

All the sources of currency risk exposure described above are operational ones. Adler and Dumas mention two more drivers of firms' exposure. First, exchange rate movements can influence the value of short- and long-term monetary assets and liabilities. Second, currency fluctuations can lead to changes in the residual value of physical assets or their replacement value [8].

Still, even if a firm is exposed to exchange rate fluctuations, it does not necessarily mean that investors would require a risk premium. If currency risk is perfectly diversifiable, then exposure to that risk does not affect firm's cost of equity. To answer the question of whether currency risk is priced, one needs to test an asset pricing model which somehow incorporates exchange rate risk.

This study is dedicated to the question of whether currency risk is priced in four emerging markets: Brazil, Russia, India and South Africa. The results obtained herein have important implications for the top management of the companies which operate in these markets. They demonstrate whether currency risk should be taken into account in the risk management process and in the valuation of a company's projects (or the whole business).

This paper is organised as follows. In the first section we review empirical studies which are dedicated to exchange rate exposure and pricing of currency risk, and which give a summary of the approaches, methods, and results of studies of interest. In the second section we outline the methodology of our research. In the third section we present the results of our estimation and discuss them. In addition, we provide a robustness check of the significance of these results. Finally, in the conclusion, we present a summary of the overall research.

\section{Literature review}

When one incorporates currency risk into an asset pricing model, two considerations should be addressed: how sizable the exposure of the asset is, and what the price of currency risk is (and, indeed, whether it is priced at all). Usually these two topics are treated in empirical literature separately: the researcher either addresses exposure and its determinants in detail or he concentrates on the existence of a currency risk premium, and exposure is only an intermediate step. In our research, we focus on the pricing of currency risk. However, determining exchange rate exposure is a necessary and important step, consequently, we review both branches of literature.

First of all, we would like to note that research results highly depend on the approach that a researcher uses. The approach used in the first studies of exchange rate expo- sure was static: it assumed that exposure does not change over time. Using this static approach and the simple basic model we described earlier, Jorion found that only $5 \%$ of international companies in the USA were significantly exposed to currency risk during 1971-1987 [9]. This result is not consistent with economic reasoning. So, in later studies researchers tried to modify Jorion's approach, explain why Jorion gained such a result, and obtain conclusions consistent with economic reasoning.

For example, Bartov and Bodnar hypothesise that investors systematically make mistakes when they respond to exchange rate changes, so securities prices need time to adjust. They analysed US companies with large foreign currency adjustments negatively correlated with growth in exchange rates between 1978 and 1989. The authors ran a pooled panel regression of abnormal equity returns on changes in exchange rates (both contemporaneous changes and changes which were lagged for one period) and found that the coefficient in front of lagged changes is significant [10]. Doidge, Griffin and Williamson also came to the conclusion that the relationship between equity returns and lagged exchange rate changes is significant for US companies (they analysed a period from 1975 to 1990). However, for other countries, this relationship is not present [11].

Several researchers suggest the existence of a nonlinear relationship between equity returns and changes in exchange rate. Koutmos and Martin examined possible asymmetries in this relationship. The authors analysed sector portfolios in Germany, Japan, Great Britain and the USA between 1992 and 1998. 40\% of portfolios were deemed to have significant exposure and $40 \%$ of significant exposures turned out to be asymmetric [12].

In the article by Aysun and Guldi, the authors tested quadratic and cubic relationship between equity returns and exchange rate changes, and modelled with different coefficients for periods with different magnitudes of exchange rate volatility, and a nonparametric model. Aysun and Guldi analysed 5 developing countries and the USA between 1995 and 2006 and came to conclusion that the percentage of exposed firms grows significantly if one uses a nonlinear model instead of the usual linear model [13]. Analysing German firms through the period from 1981 to 1995, Bartram also concluded that allowing for nonlinear exposure leads to a higher percentage of exposed firms [14].

Some researchers hypothesise that it's the static approach that leads to implausible results. Chaieb and Mazzotta found that currency risk exposure is time-varying in their analysis of equity returns of US companies between 1973 and 2005, using a conditional model where exposure varies with changes in business cycle indicators [15]. Evidence of time-varying exposure and the fact that allowing for it leads to a higher percentage of exposed firms is present in several other articles [16-18].

As for determinants of exchange rate exposure, first of all, the degree and direction of exposure is different for firms from different sectors [19-21]. Secondly, there are several factors that consistently tend to have the same effect in 
various studies. Doidge, Griffin and Williamson found that the level of exchange rate exposure is higher for firms with a higher percentage of foreign sales and lower for larger firms [11]. Similar results are found in other studies [22-24]. However, sometimes size is not significant [14] and rarely even has a positive impact on exposure [25]. The impact of company size on exchange rate exposure can depend on the market where the firm operates. For example, Jeon, Zheng, and Zhu claim that in emerging markets larger firms have higher exposure because of their global connections, while in advanced economies small firms are more exposed since they have fewer opportunities to hedge [26].

Moreover, there is not yet enough evidence of the impact of many other proposed determinants of exposure. Aggarwal and Harper note that there is a positive relationship between the level of exposure and financial leverage (market-to-book equity ratio), and a negative relationship between level of exposure and asset turnover [7]. Agyei-Ampomah, Mazouz and Yin also find that financial leverage increases the level of exposure of firms in Great Britain, but find an opposite result for the impact of market-to-book ratio [18]. In contrast, $\mathrm{He}, \mathrm{Ng}$ analysed the exposure of Japanese international companies and found that higher financial leverage leads to lower exposure. This is explained by the fact that firms with high financial leverage are less likely to risk the financial stability of the firm and prefer to hedge currency risk [27].

A firm's technical characteristics are not the only factors influencing the exposure of a company. Managerial incentives also play a crucial role in determining the exchange rate exposure of a firm. For example, Francis, Hasan, Hunter, and Zhu use the sensitivity of managers' compensation to stock price changes (delta) and to volatility of stock returns (vega) to find out whether top management's incentives influence exposure to currency risk. Previously, it has been shown that a higher delta increases the risk-aversion of managers while a higher vega leads to higher tolerance of risk. Indeed, Francis et al. foundnd that delta reduces exposure to currency risk whereas vega increases it [28].

Moving on to the second branch of literature, one of the first studies dedicated to pricing of exchange risk is an article by Jorion, where he tested a local CAPM with exchange rate risk and an APT model with exchange rate risk using US data throughout the period from 1971-

1987. According to Jorion's findings, currency risk premia are insignificant, i.e. currency risk is perfectly diversifiable and is not priced by investors. However, the author himself notes that his approach is static and the assumption of constant beta-coefficients and a constant risk premium might be impractical in reality [19].

A similar static local CAPM-based approach was implemented by Bailey and Chung who analysed Mexican data from 1986 to 1994. The authors did not find evidence for an unconditional currency risk premium, however, they state that there exists indirect evidence of time-varying exchange rate risk premia [29].
Nevertheless, not all studies with a static approach fail to detect significant currency risk premia. Vassalou tests a static international CAPM using data on 10 countries from 1973 to 1990 . She constructed 2 indices based on 9 exchange rates: a 'common component' index and a 'residual exchange' rate index. Also the model is extended by including inflation risk. As a result, she concluded that in 6 out of 10 countries at least one type of exchange rate risk is significant [30].

Dynamic and conditional approaches turn out to be successful in terms of finding a significant risk premium. Dumas and Solnik tested both static (unconditional) and conditional international CAPMs using data from Germany, Japan, UK and the USA from 1970 to 1991. In an unconditional model currency risk is insignificant while in a conditional model currency risk is significant [31].

Krapl and Giacotto estimate a conditional international CAPM using US data from 1978 to 2011 and came to the conclusion that currency risk premium is significant. Interestingly, they also state that for cash flows received in the near future, the currency risk premium is positive while for cash flows received in the longer term, the exchange rate premium is negative [32].

Unlike the previously discussed researchers, Doukas, Hall and Lang base their study on the Fama-French Three Factor Model. They also include several macroeconomic variables as explanatory variables. The exchange rate risk factor is estimated on the basis of the "Eurodollar interest rate compounded by the Yen variation relative to the US dollar". The authors analysed the Japanese market throughout the period from 1975 to 1995 and conclude that currency risk is priced. However, when they tested this statement, they did not estimate and test premia for significance, but used indirect tests [33].

Francis, Hasan and Hunter estimated the Fama French Three Factor Model and added in two currency factors: one based on changes in major partners' currency index, and another based on changes in the currency index for other important trading partners. In the analysis, US data from 1980 to 1999 was used. Both currency risk premia turn out to be significant and time-varying [17].

Azher and Iqbal estimated the Fama French Three Factor Model, and extended it by including not only local market risk factor, but also a world market risk factor, and included changes in the bilateral exchange rate of domestic currency against the US dollar as the currency risk factor. They estimated this model for Pakistan's equity market over the period from 1993 to 2013 and find negative significant currency risk premium [34].

Kolari, Moorman and Sorescu tested the Four Factor Carhart model using US data from 1973 to 2002 . They estimated the currency risk factor based on the difference in returns between firms which are exposed to exchange rate changes and those which are not (exposure is measured as a sensitivity of returns to changes in the exchange rate). The researchers found a significant negative risk premium [35]. 
$\mathrm{Du}$ and $\mathrm{Hu}$ redid the analysis of Kolari, Moorman and Sorescu, but used different portfolios in their analysis. Firstly, they redid the analysis with industry portfolios. Secondly, they estimated the exposure of firms in more robust ways (they excluded outliers, or used a longer estimation window, or used the least absolute deviations regressions). In all these cases, significant currency risk premium is seen to disappear [36].

Apergis, Artikis and Sorros estimated a local CAPM, Fama-French Three Factor Model and a Carhart Four Factor Model, adding a currency risk factor constructed in the same manner as in the article by Kolari, Moorman and Sorescu. German data from 2000 to 2008 was used, but the currency premium is not directly estimated. However, the authors state that currency risk is a pricing factor since the model's error (intercept) is reduced when the currency factor is added [37].

In another article, $\mathrm{Du}$ and $\mathrm{Hu}$ offer an alternative way to estimate firms' exposure to currency risk. They regress changes in cash flows normalised by assets on changes in currency value and treat this coefficient as currency risk exposure. Analysing US data from 1980 to 2008, the authors tested a Carhart Four Factor Model without a high-minus-low factor, but with a currency factor, and concluded that currency risk premium is significant and usually positive [38].

Alternatively, one can try volatility of exchange rate as a base for a currency risk factor: it could be either a change in volatility or the difference in returns of currency volatility between sensitive and insensitive firms. Du and Hu use US data from 1973 to 2010 and estimated CAPM and Carhart Four Factor Model with a currency volatility risk factor. The authors failed to obtain a conclusion of a significant currency risk premium [39].

An interesting approach was introduced in the study by Armstrong, Knif, Kolari and Pynnonen. They extended the Fama-French Three Factor model by adding changes in exchange rate and cross-products of Fama-French factors and changes in exchange rate. Using US data from 1975 to 2008, the authors concluded that changes in the exchange rate influence sensitivities of assets to market risk, but a separate currency risk premium is not significant [40].

\section{Methodology}

In this research, we extend the Fama-French Three Factor Model [41] by adding currency-risk factors. To estimate the resulting risk premia, we use a portfolio approach to reduce the impact of the specific risks of each company on empirical results. Risk premia are estimated using a twostep Fama-MacBeth procedure [42]. Also, we use weekly (as opposed to monthly) returns due to the shortness of the period which is available for analysis.

The main question is how to construct the currency risk factors that we incorporate in the Fama-French Three Factor Model. Considering the limitations of data on most of the emerging markets, there are two ways to do this.
We can use currency gain information from income statements, and we can use the level of covariance between a company's stock returns and its currency returns. Using these two approaches, we estimate three models that extend the Fama-French Three Factor Model by adding currency risk factors.

Firstly, we form the currency risk factor on the basis of the difference between companies which have a relatively high absolute value of a currency gains-to-sales ratio, and companies with low absolute value of this ratio. The intuition behind this is that no matter whether company gained or lost because of exchange rate fluctuations, the fact that it is exposed to changes in currency value signals that the company is risky. Pertinent to this point is the fact that realised exposure is quite substantial relative to the size of a company's operations. Assuming investors cannot perfectly diversify a company's currency risk, he or she will demand a higher expected return. We call the corresponding risk factor "exposed minus zero" (EMZ) and incorporate it into the Fama-French Three Factor model (Model 1):

$$
\begin{aligned}
& \mathbb{E}\left(r_{i}-r_{f}\right)=\beta_{i} \mathbb{E}\left(r_{m}-r_{f}\right)+s_{i} \mathbb{E}(S M B)+ \\
& +h_{i} \mathbb{E}(H M L)+e_{i} \mathbb{E}(E M Z)
\end{aligned}
$$

where $r_{i}$ is return on asset $\mathrm{i}, r_{f}$ is risk-free rate of return, $r_{m}$ is return on market portfolio, $\mathbb{E}(S M B)$ is size premium (expected difference in return on small and big companies, "small minus big"), $\mathbb{E}(H M L)$ is value premium (expected difference in return on value stocks (high book-to-market) and growth stocks (low book-to-market), "high minus low"), $\mathbb{E}(E M Z)$ is currency premium (expected difference in returns on stocks exposed to currency risk and not exposed, "exposed minus zero").

To estimate this model, firstly, we calculate risk factors in the manner used by Fama and French [41]. To do this we need to construct 8 portfolios: 2 equal groups by absolute value of currency gain-to-sales ratio (as reported in financial statements for the year ended before period begins), 2 equal groups by size (measured as market capitalisation just before the period begins), 2 equal groups by book-tomarket equity ratio (measured as the book value of equity to market capitalisation at the end of the year which ended before the analysed period begins). Then we intersect these groups. Afterwards, we calculate risk factors SMB, HML, EMZ:

$$
\begin{aligned}
S M B_{t} & =\frac{\sum_{i=1}^{4} r_{i t}^{\text {small }}}{4}-\frac{\sum_{i=1}^{4} r_{i t}^{\text {big }}}{4} \\
H M L_{t} & =\frac{\sum_{i=1}^{4} r_{i t}^{\text {high }}}{4}-\frac{\sum_{i=1}^{4} r_{i t}^{\text {low }}}{4} \\
E M Z_{t} & =\frac{\sum_{i=1}^{4} r_{i t}^{\text {exposed }}}{4}-\frac{\sum_{i=1}^{4} r_{i t}^{\text {not expozed }}}{4}
\end{aligned}
$$


where $r_{i t}^{\text {small }}$ is the return on one of four portfolios considered small at time $t$, and the other variables are self-explanatory.

After we calculated all the risk factors, we proceed to dependent variable calculation, used in estimation of our first model. To do it, we form 20 new portfolios. First, the sample is divided into 5 equal groups based on the absolute value of the currency gain-to-sales ratio. Second, each currency group is divided into 4 equal groups based on book-to-market value. Overall, we have 20 portfolios and their returns are used as dependent variables in further estimation of Model 1.

Secondly, there is a possibility that investors treat companies which have a highly positive currency gain-to-sales ratio and those with a highly negative currency gain-tosales ratio differently. Perhaps it is considered that only negative currency gain is a bad signal. Whether a company has a positive or negative currency gain depends on a lot of factors: the direction of exchange rate change, and whether the company has a "long" or "short" position in the currency. Moreover, it is not only the nature of the firm's business which determines whether position is "long" or "short", but also the exact actions taken by a company's management. Therefore, it is impossible to see what stands behind positive or negative currency gain without a deep analysis of a firm's business. Nevertheless, investors might naturally interpret negative currency gain as a worse signal as compared to positive currency gains.

So, the second model is based on adding two currency risk factors to the Fama-French Three Factor model. One factor is calculated as the difference between firms that have highly positive currency gain-to-sales ratio and those companies with this ratio close to zero ("positive minus zero", PMZ). The other factor is calculated as the difference between firms that have a highly negative currency gain-to-sales ratio and companies with this ratio close to zero ("negative minus zero", NMZ). The model looks as follows (Model 2):

$$
\begin{aligned}
& \mathbb{E}\left(r_{i}-r_{f}\right)=\beta_{i} \mathbb{E}\left(r_{m}-r_{f}\right)+s_{i} \mathbb{E}(S M B)+ \\
& +h_{i} \mathbb{E}(H M L)+e p_{i} \mathbb{E}(P M Z)+e n_{i} \mathbb{E}(N M Z)
\end{aligned}
$$

To estimate this version of an asset pricing model we construct 12 portfolios: two equal portfolios by size, two equal portfolios by book-to-market ratio and three equal portfolios by a currency gain-to-sales ratio. Then, we intersect these groups and calculate risk factors as follows:

$$
\begin{aligned}
& S M B_{t}=\frac{\sum_{i=1}^{6} r_{i t}^{\text {small }}}{6}-\frac{\sum_{i=1}^{6} r_{i t}^{\text {big }}}{6}, \\
& H M L_{t}=\frac{\sum_{i=1}^{6} r_{i t}^{\text {high }}}{6}-\frac{\sum_{i=1}^{6} r_{i t}^{\text {low }}}{6},
\end{aligned}
$$

$P M Z_{t}=\frac{\sum_{i=1}^{4} r_{i t}^{\text {positive }}}{4}-\frac{\sum_{i=1}^{4} r_{i t}^{\text {zero }}}{4}$

$N M Z_{t}=\frac{\sum_{i=1}^{4} r_{i t}^{\text {negative }}}{4}-\frac{\sum_{i=1}^{4} r_{i t}^{\text {zero }}}{4}$.

Afterwards, we construct 20 new portfolios to calculate the dependent variable used in estimation of Model 2. Firstly, the sample is divided into 5 equal groups based on the value of currency gain-to-sales ratio. Then, each group is divided into 4 equal groups based on book-to-market value.

Finally, a completely different approach is to use the extent to which company's returns and currency returns covary. Based on the article by Koutmos and Martin, we estimate the exchange rate exposure of a company using the following model [18]:

$$
\begin{aligned}
& r_{j, t}={ }_{j}+{ }_{j, \text { market }} r_{m, t}+{ }_{j, \text { currency }}^{+} r_{c, t}^{+}+ \\
& +_{j, \text { currency }}^{-} r_{c, t}^{-}+{ }_{j, t}
\end{aligned},
$$

where $r_{c, t}^{+}$is change in exchange rate (domestic currency per US dollar) multiplied by a dummy variable which takes value 1 if currency return is positive (currency depreciates) and $r_{c, t}^{-}$is the change in exchange rate multiplied by dummy variable which takes value 1 if currency return is negative (currency appreciates), other variables are self-explanatory. Here we allow currency risk exposure to be asymmetric (since it has been shown in the literature that exchange rate exposure is indeed asymmetric), and neither the Russian nor the Brazilian market is an exception [43]. Exposure is estimated over 115 observations before each of the 6 periods end.

We use a bilateral exchange rate because effective exchange rates are not available on a weekly basis. Among all bilateral exchange rates we use the exchange rate of domestic currency against the US dollar because the US dollar is the currency which is most often used in international trade contracts, at least when it comes to companies from emerging markets. For example, in Brazil the percentage of international trade contracts with the US dollar used as the transaction currency is $80-90 \%$ [44].

The question is whether the relationship between currency exposure and risk as perceived by investors as linear or not. On the one hand, it seems that any kind of exposure to the exchange rate changes poses a risk. Both exporters and importers (or companies with debt denominated in foreign currency) are riskier than companies that are "immune" to currency risk. Therefore, investors should demand a risk premium for that. However, it should not simply be assumed to be the case, especially not the fact that investors demand the same premium for positive and negative currency gain exposure of the same magnitude.

So, to estimate our final model we form 36 portfolios. First, we divide our sample into 3 equal groups by curren- 
cy beta plus (exposure to depreciation of currency) and into 3 equal groups by currency beta minus (exposure to appreciation of currency). We intersect these groups and get 9 portfolios. Then each group is divided in two equal ones based on size. Then again, each group is divided in two equal ones based on book-to-market value. Here we do not divide our sample independently because the limited amount of companies available might result in many empty portfolios. The model appears as follows (Model 3):

$$
\begin{aligned}
& \mathbb{E}\left(r_{i}-r_{f}\right)=\beta_{i} \mathbb{E}\left(r_{m}-r_{f}\right)+s_{i} \mathbb{E}(S M B)+ \\
& +h_{i} \mathbb{E}(H M L)+e p_{i}^{+} \mathbb{E}\left(P M Z^{+}\right)+ \\
& +e p_{i}^{-} \mathbb{E}\left(P M Z^{-}\right)+e n_{i}^{+} \mathbb{E}\left(N M Z^{+}\right)+ \\
& +e n_{i}^{-} \mathbb{E}\left(N M Z^{-}\right)
\end{aligned}
$$$$
S M B_{t}=\frac{\sum_{i=1}^{18} r_{i t}^{\text {small }}}{18}-\frac{\sum_{i=1}^{18} r_{i t}^{\text {big }}}{18}
$$$$
H M L_{t}=\frac{\sum_{i=1}^{18} r_{i t}^{\text {high }}}{18}-\frac{\sum_{i=1}^{18} r_{i t}^{\text {low }}}{18}
$$$$
\mathrm{PMZ}_{t}^{+}=\frac{\sum_{i=1}^{12} r_{i t}^{\text {positive currency beta }}{ }^{+}}{12}-
$$$$
\sum_{i=1}^{12} r_{i t}^{\text {zero currency beta }}
$$$$
12
$$$$
\mathrm{PMZ}_{t}^{-}=\frac{\sum_{i=1}^{12} r_{i t}^{\text {positive currency beta }}{ }^{-}}{12}-
$$$$
\sum_{i=1}^{12} r_{i t}^{\text {zero currency beta }}
$$$$
12
$$$$
\mathrm{NMZ}_{t}^{+}=\frac{\sum_{i=1}^{12} r_{i t}^{\text {negative currency beta }}{ }^{+}}{12}-
$$$$
-\frac{\sum_{i=1}^{12} r_{i t}^{\text {zero currency beta }}{ }^{+}}{12}
$$$$
\mathrm{NMZ}_{t}^{+}=\frac{\sum_{i=1}^{12} r_{i t}^{\text {negative currency beta }}}{12}-
$$$$
-\underline{\sum_{i=1}^{12} r_{i t}^{\text {zero currency beta }}}
$$

Next we construct 18 new portfolios to calculate the dependent variable for the estimation of Model 3. First, we divide the sample into 3 equal groups based on the value of currency beta plus (exposure to depreciation of exchange rate) and 3 equal groups depending on the value of currency beta minus (exposure to appreciation of exchange rate). Then we intersect these groups to get 9 portfolios. Then again, each of 9 groups is divided into 2 equal parts depending on book-to-market value. Overall, there are 18 portfolios and their returns are used as a dependent variable series in estimation of Model 3.

To estimate each model, we use Fama-MacBeth procedure with a rolling window. To account for resulting autocorrelation we calculate Newey-West standard errors. The first step is to run a time-series regression for each portfolio used to calculate dependent variable. This regression is run over 115 observations (approximately two years):

$$
\begin{aligned}
& \left(r_{i}-r_{f}\right)_{t}=\delta_{i}+\beta_{i}\left(r_{m}-r_{f}\right)_{t}+s_{i} S M B_{t}+ \\
& +h_{i} H M L_{t}+\sum_{m=1}^{M} e_{m i} C F_{m t}+\vartheta_{i t}
\end{aligned},
$$

where $\left(r_{i}-r_{f}\right)_{t}$ is excess return on portfolio i over week $\mathrm{t},\left(r_{m}-r_{f}\right)_{t}$ is excess return on market portfolio over week t, $S M B_{t}$ is SMB risk factor calculated before for week t, $H M L_{t}$ is HML risk factor calculated before for week t, $C F_{m t}$ is currency risk factor number m calculated before for week $\mathrm{t}$. The amount of currency risk factors and their meaning depend on the type of model that we estimate.

We estimate a system of 20 equations (18 in the case of Model 3), which take form (18) together, using a seemingly unrelated regression estimation method. Then the window is shifted by one week.

Overall, we get 251 estimates for each coefficient of each portfolio and use them in the second step. Here, for each window $\mathrm{k}$ we run a cross-section regression (overall 251 regressions):

$$
\begin{aligned}
& \overline{\left(r_{i}-r_{f}\right)_{k}}=\mu_{k}+\widehat{\beta}_{i k} \gamma_{k}^{M R P}+\widehat{s}_{i k} \gamma_{k}^{S M B}+ \\
& +\widehat{h}_{i k} \gamma_{k}^{H M L}+\sum_{m=1}^{M} \widehat{e_{m i}} \gamma_{k}^{m}+\eta_{i k}
\end{aligned}
$$

where $\overline{\left(r_{i}-r_{f}\right)_{k}}$ is excess return of portfolio i averaged over window $\mathrm{k}, \gamma_{k}^{M R P}, \gamma_{k}^{S M B}, \gamma_{k}^{H M L}, \gamma_{k}^{1}, \ldots, \gamma_{k}^{M}$ are correspondingly market, size, value and currency risk premia to be estimated.

Finally, we average estimates of premia from the previous step and check them for significance (using Newey-West standard errors). 


\section{Data and sample}

In this research, we use company level data on firms which are traded in capital markets of Brazil, Russia, India and South Africa. All the data is obtained from Thomson Reuters Datastream. The research covers a period from July 2009 to June 2016. We do not use data from before then because in Russia and Brazil prior to July 2008 there were not enough liquid nonfinancial companies with all information that we need. The period from July 2008 to June 2009 is excluded because market indices were falling sharply during this period, which might affect the reliability of our results. Let us consider the data in table 1, which reports the amount of liquid companies in Russia, Brazil, India and South Africa. In Russia 117 liquid companies are included in the estimation sample for 2015, in Brazil - 116, in India - 303, and in South Africa - 128. The stock market of India is more developed and the number of stocks available for analysis is higher there. Also, table A1 presents a sectoral breakdown of Russia's liquid companies during the entire period from 2009 to 2015 . The largest number of liquid companies in Russia's sectoral background for 2015 are 'basic materials' followed by 'utilities', and then 'industrials' Table A2 presents a breakdown of Brazil's liquid companies during the period from 2009 to 2015. The largest number of liquid companies in Brazil's sectoral background are those of 'consumer goods', followed by 'industrials', then 'consumer services'. Table A3 presents a breakdown of India's liquid companies during the entire period from 2009 to 2015 . The largest number of liquid companies in India's sectoral background are 'industrials', followed by 'consumer goods', and then 'basic materials'. Table A4 presents breakdown of South Africa's liquid companies during the entire period from 2009 to 2015. The largest number of liquid companies in South Africa's sectoral background are 'industrials', followed by 'basic materials', and then 'consumer services'.

Table 1. Liquid companies in Russia, Brazil, India and South Africa in 2015

\begin{tabular}{|c|c|c|c|c|c|c|c|c|}
\hline \multirow[b]{2}{*}{ Industry/Country } & \multicolumn{2}{|c|}{ Russia } & \multicolumn{2}{|c|}{ Brazil } & \multicolumn{2}{|c|}{ India } & \multicolumn{2}{|c|}{ South Africa } \\
\hline & $\begin{array}{l}\text { Number of } \\
\text { securities }\end{array}$ & $\begin{array}{c}\% \\
\text { of total }\end{array}$ & $\begin{array}{l}\text { Number of } \\
\text { securities }\end{array}$ & $\begin{array}{c}\% \\
\text { of total }\end{array}$ & $\begin{array}{l}\text { Number of } \\
\text { securities }\end{array}$ & $\begin{array}{c}\% \\
\text { of total }\end{array}$ & $\begin{array}{l}\text { Number of } \\
\text { securities }\end{array}$ & $\begin{array}{c}\% \\
\text { of total }\end{array}$ \\
\hline Oil \& Gas & 11 & $9 \%$ & 9 & $8 \%$ & 13 & $4 \%$ & 4 & $3 \%$ \\
\hline Basic Materials & 32 & $27 \%$ & 11 & $9 \%$ & 46 & $15 \%$ & 26 & $20 \%$ \\
\hline Industrials & 18 & $15 \%$ & 22 & $19 \%$ & 81 & $27 \%$ & 44 & $34 \%$ \\
\hline Consumer Goods & 6 & $5 \%$ & 28 & $24 \%$ & 71 & $23 \%$ & 13 & $10 \%$ \\
\hline Health Care & 5 & $4 \%$ & 6 & $5 \%$ & 30 & $10 \%$ & 5 & $4 \%$ \\
\hline Consumer Services & 9 & $8 \%$ & 18 & $16 \%$ & 19 & $6 \%$ & 21 & $16 \%$ \\
\hline Telecommunications & 6 & $5 \%$ & 4 & $3 \%$ & 5 & $2 \%$ & 5 & $4 \%$ \\
\hline Utilities & 29 & $25 \%$ & 16 & $14 \%$ & 17 & $6 \%$ & 0 & $0 \%$ \\
\hline Technology & 1 & $1 \%$ & 2 & $2 \%$ & 21 & $7 \%$ & 10 & $8 \%$ \\
\hline Total & 117 & $100 \%$ & 116 & $100 \%$ & 303 & $100 \%$ & 128 & $100 \%$ \\
\hline
\end{tabular}

Source: Thomson Reuters Datastream and authors' own calculations.

Table 2. Periods at the beginning of which portfolios are reformed

\begin{tabular}{|c|c|c|}
\hline Period & Start & End \\
\hline 1 & 29.06 .09 & 27.06 .10 \\
\hline 2 & 28.06 .10 & 26.06 .11 \\
\hline 3 & 27.06 .11 & 24.06 .12 \\
\hline 4 & 25.06 .12 & 23.06 .13 \\
\hline 5 & 24.06 .13 & 29.06 .14 \\
\hline 6 & 30.06 .14 & 28.06 .15 \\
\hline 7 & 29.06 .15 & 26.06 .16 \\
\hline
\end{tabular}

So, we have seven periods each starting from the last Monday of June. At the beginning of each period, we form portfolios used to calculate dependent and explanatory variables. The end of June is chosen as a starting point because at this moment all public companies manage to publish their annual reports and information from these reports is reflected in the prices of companies' shares. We use an equal-weighted portfolio approach for our estimations.

The yield-to-maturity for 3-month government bonds serves as a proxy for a risk-free rate. Market indices are used as proxies for market portfolios. In the case of Russia it is the MICEX index, in Brazil the BOVESPA index, in India the NIFTY 50, and in South Africa the FTSE/JSE All Shares index. 
Before forming portfolios we need to select nonfinancial companies which are liquid enough during the period of interest. A company is considered to be liquid if during the period of interest it is traded on average at least two times a week and the average weekly trading value is at least 5 million Russian rubles (274 thousand Brazilian reals, 1.1 million South African rands, 4.9 million Indian rupiahs) as per July 2015 - June 2016 prices.

\section{Empirical Results}

The results of the estimation for Russia, Brazil, India and South Africa are presented in Tables 3, 4, 5 and 6, respectively. In general, in all tables the premiums of standard factors (market risk premium, size premium, and growth / value premium) are estimated imprecisely with this set of base assets. Ang shows that market risk premiums, size premiums and growth/value premiums might be insignificant during some periods [45].

In the case of Russia, a currency risk premium for positive exposure to depreciation of currency (exporters) is positive and significant in model 3. This is something one would naturally expect. Being exposed to currency movements, exporters are riskier than firms with no exposure and investors require a risk premium for that. What one would not expect is a negative risk premium attached for negative exposure to depreciation of the national currency. Negative exposure means that a company is an importer or has debt denominated in foreign currency. In addition, there is a significant negative risk premium for positive exposure of exporters to currency appreciation. Note that in both cases a company has a negative risk premium for exposure to unfavourable movements of exchange rate.

Table 3. Estimation results for Russia

\begin{tabular}{|c|c|c|c|}
\hline & Model 1 & Model 2 & Model 3 \\
\hline \multirow[t]{2}{*}{ Market risk premium $\left(r_{m}-r_{f}\right)$} & 0.00220 & 0.00610 & -0.00010 \\
\hline & $(2.0362)$ & $(3.6601)$ & $(12.6863)$ \\
\hline \multirow[t]{2}{*}{ Size premium $(S M B)$} & 0.00160 & -0.00150 & 0.00130 \\
\hline & $(0.7511)$ & $(1.0686)$ & $(0.7853)$ \\
\hline \multirow[t]{2}{*}{ Growth/value premium $(H M L)$} & -0.00040 & 0.00020 & 0.00050 \\
\hline & $(0.2207)$ & $(0.2638)$ & $(0.2386)$ \\
\hline \multicolumn{4}{|l|}{ Currency premia } \\
\hline \multirow[t]{2}{*}{$E M Z$} & 0.00150 & & \\
\hline & $(0.1848)$ & & \\
\hline \multirow[t]{2}{*}{$P M Z$} & & 0.00100 & \\
\hline & & $(0.3167)$ & \\
\hline \multirow[t]{2}{*}{$N M Z$} & & 0.00370 & \\
\hline & & $(0.6989)$ & \\
\hline \multirow[t]{2}{*}{$P M Z^{+}$} & & & $0.0036^{\star * *}$ \\
\hline & & & $(0.2392)$ \\
\hline \multirow[t]{2}{*}{$P M Z^{-}$} & & & -0.00070 \\
\hline & & & $(0.1844)$ \\
\hline \multirow[t]{2}{*}{$N M Z^{+}$} & & & 0.00000 \\
\hline & & & $(0.325)$ \\
\hline \multirow[t]{2}{*}{$N M Z^{-}$} & & & 0.00150 \\
\hline & & & $(0.2722)$ \\
\hline \multirow[t]{2}{*}{ Intercept } & 0.00100 & -0.00140 & 0.00300 \\
\hline & $(1.0233)$ & $(1.8674)$ & (7.8789) \\
\hline
\end{tabular}

Note: Table reports risk premia. The first figure corresponds to weekly risk premium and the second one (separated by a slash, "/”) corresponds to an annual risk premium. Figures in brackets are Newey-West standard errors. “***” determines coefficients which are significant at a $1 \%$ significance level, “ $¥ *$ ” - at a $5 \%$ significance level, “ ” - at a $10 \%$ confidence level. 
Table 4. Estimation results for Brazil

\begin{tabular}{|c|c|c|c|}
\hline & Model 1 & Model 2 & Model 3 \\
\hline \multirow[t]{2}{*}{ Market risk premium $\left(r_{m}-r_{f}\right)$} & -0.00370 & 0.00620 & -0.00410 \\
\hline & $(9.972)$ & $(18.8101)$ & $(11.5672)$ \\
\hline \multirow[t]{2}{*}{ Size premium $(S M B)$} & 0.00120 & -0.00040 & 0.00160 \\
\hline & $(0.474)$ & $(0.5855)$ & $(0.6428)$ \\
\hline \multirow[t]{2}{*}{ Growth/value premium ( $H M L)$} & -0.00040 & 0.00090 & -0.00290 \\
\hline & $(0.1186)$ & $(0.2013)$ & $(0.209)$ \\
\hline
\end{tabular}

Currency premia

\begin{tabular}{|c|c|c|}
\hline$E M Z$ & $-0.0016^{\star *}$ & \\
\hline & $(0.0971)$ & \\
\hline \multirow[t]{2}{*}{$P M Z$} & & $-0.0023^{*}$ \\
\hline & & $(0.2342)$ \\
\hline \multirow[t]{2}{*}{$N M Z$} & & $-0.0031^{\star}$ \\
\hline & & $(0.3913)$ \\
\hline
\end{tabular}

$\mathrm{PMZ}^{+}$

(0.9099)

$N M Z^{+}$

$-0.00230$

(1.4524)

$\begin{array}{ll}N Z^{-} & -0.00020\end{array}$

0.
Intercept

Note: Table reports risk premia. The first figure corresponds to weekly risk premium and the second one (separated by slash, "/") corresponds to annual risk premium. Figures in brackets are Newey-West standard errors. "***” determines coefficients which are significant at $1 \%$ significance level, “**” - at 5\% significance level, “*” - at 10\% confidence level.

In the case of Brazil, currency risk premiums based on currency gains value are negative and significant in both specifications (Model 1 and 2). It seems that investors require a lower expected return from companies which report nonzero currency gains. As we discussed previously, this might lead to expected return decreasing as uncertainty increases.

In the case of India different types of currency risk premia have different signs. Similarly to Russian stock market, the sign of a risk premium depends on whether the company wins or loses from exchange rate change. If the company is highly exposed to favourable changes in exchange rate, investors demand a substantial risk premia $(0.29 \%$ per week if company is positively exposed to appreciation of currency, i.e. it is an exporter, and $0.27 \%$ per week if the company is negatively exposed to depreciation of national currency, i.e. it is an importer or has debt denominated in foreign currency). Being exposed to unfavourable exchange rate change leads to a lower expected return $(-0.11 \%$ per week if the company is negatively exposed to appreciation of currency). 
Table 5. Estimation results for India

\begin{tabular}{|c|c|c|c|}
\hline & Model 1 & Model 2 & Model 3 \\
\hline \multirow[t]{2}{*}{ Market risk premium $\left(r_{m}-r_{f}\right)$} & -0.00170 & 0.00920 & 0.01930 \\
\hline & $(1.6508)$ & $(14.319)$ & $(3.4055)$ \\
\hline \multirow[t]{2}{*}{ Size premium $(S M B)$} & 0.00290 & 0.00120 & 0.00010 \\
\hline & $(0.3856)$ & $(0.8152)$ & $(0.3721)$ \\
\hline \multirow[t]{2}{*}{ Growth premium ( $H M L$ ) } & 0.00080 & 0.00150 & 0.00160 \\
\hline & $(0.2157)$ & $(0.26)$ & $(0.2446)$ \\
\hline
\end{tabular}

Currency premia

EMZ

\begin{tabular}{|c|c|}
\hline$P M Z$ & -0.00220 \\
\hline & $(0.2656)$ \\
\hline \multirow[t]{2}{*}{$N M Z$} & 0.00110 \\
\hline & $(0.559)$ \\
\hline
\end{tabular}

$P M Z^{+}$

$-0.00070$

(0.0487)

$P M Z^{-}$

$0.003^{\star *}$

$(0.2752)$

$N M Z^{+}$

$0.0027^{\star}$

$(0.2947)$

$N M Z^{-}$

$-0.0011^{\star}$

$(0.0554)$

\begin{tabular}{|c|c|c|c|}
\hline Intercept & $0.0039^{*}$ & -0.00350 & $-0.0096^{* * *}$ \\
\hline & $(0.6307)$ & $(5.8535)$ & $(1.4841)$ \\
\hline
\end{tabular}

Note: Table reports risk premia. The first figure corresponds to weekly risk premium and the second one (separated by slash, "/") corresponds to annual risk premium. Figures in brackets are Newey-West standard errors. "***” determines coefficients which are significant at $1 \%$ significance level, “**” - at 5\% significance level, “*” - at 10\% confidence level.

In the case of South Africa, the currency risk premium based on currency gains to sales ratio is significantly negative. Separating companies with positive and negative currency gains does not change this result.

Moving to model 3, being exposed to currency depreciation leads to paying a significantly positive risk premium
( $0.147 \%$ in case of positive exposure). Risk premium for positive exposure to appreciation of domestic currency is insignificant, indicating that investors do not require a risk premium in this case. Having negative exposure to currency appreciation leads to paying a lower required return on equity. 
Table 6. Estimation results for South Africa

\begin{tabular}{|c|c|c|c|}
\hline & Model 1 & Model 2 & Model 3 \\
\hline \multirow[t]{2}{*}{ Market risk premium $\left(r_{m}-r_{f}\right)$} & -0.00170 & -0.00310 & -0.00570 \\
\hline & $(0.9243)$ & $(0.9888)$ & (3.0274) \\
\hline \multirow[t]{2}{*}{ Size premium $(S M B)$} & 0.00080 & 0.00250 & 0.00040 \\
\hline & $(0.9269)$ & $(0.478)$ & $(0.5568)$ \\
\hline \multirow[t]{2}{*}{ Growth premium ( $H M L)$} & 0.00000 & -0.00190 & 0.00020 \\
\hline & $(0.1769)$ & $(0.356)$ & $(0.1747)$ \\
\hline
\end{tabular}

Currency premia

$E M Z$

$(0.1551)$

\begin{tabular}{|c|c|c|c|}
\hline \multirow[t]{2}{*}{$P M Z$} & \multicolumn{3}{|c|}{$-0.0031^{\star * *}$} \\
\hline & \multicolumn{3}{|c|}{$(0.1826)$} \\
\hline \multirow[t]{2}{*}{$N M Z$} & \multicolumn{3}{|c|}{-0.00270} \\
\hline & \multicolumn{3}{|c|}{$(0.3869)$} \\
\hline \multirow[t]{2}{*}{$P M Z^{+}$} & & & $0.0015^{\star *}$ \\
\hline & & & $(0.0769)$ \\
\hline \multirow[t]{2}{*}{$P M Z^{-}$} & & & 0.00000 \\
\hline & & & $(0.0743)$ \\
\hline \multirow[t]{2}{*}{$N M Z^{+}$} & & & 0.00030 \\
\hline & & & $(0.0767)$ \\
\hline \multirow[t]{2}{*}{$N M Z^{-}$} & & & -0.00060 \\
\hline & & & $(0.0807)$ \\
\hline \multirow[t]{2}{*}{ Intercept } & $0.0033^{\star *}$ & $0.0042^{\star * *}$ & $0.0063^{\star * *}$ \\
\hline & $(0.3381)$ & $(0.3815)$ & $(0.8694)$ \\
\hline
\end{tabular}

Note: Table reports risk premia. The first figure corresponds to weekly risk premium and the second one (separated by slash, "/”) corresponds to annual risk premium. Figures in brackets are Newey-West standard errors. "**** determines coefficients which are significant at $1 \%$ significance level, “**” - at 5\% significance level, “»” - at 10\% confidence level

Comparing the results which we obtained for different countries, firstly, it should be noted that when we proxy currency risk by currency gains-to-sales ratio, we obtain qualitatively different results for Russia and for three other countries. In Russia, if the company publishes negative or positive currency gains, it pays a higher positive return on equity. However, only a currency risk premium for positive exposure to depreciation of currency is significant in model 3. Similar results were received for South Africa. There is a significant currency risk premium for positive exposure to depreciation of currency in model 3. It is in- advisable to directly compare results for India and South Africa, though, because in India currency risk premiums in model 1 and 2 are not significant.

In Brazil, India and South Africa, firms with highly positive or negative currency gains face negative currency risk premia. Such a difference can be explained by the fact that during recent years Russia faced the most substantial currency depreciation among the countries analysed in this research. Since November 2014 when the Central Bank of Russia introduced the floating exchange rate regime, the volatility of domestic currency against the US dollar 
increased significantly [46]. This change was initially perceived by businesses as a negative one since it makes results of international trade operations more uncertain and complicates doing business in general by increasing macroeconomic uncertainty [47]. Such events might be behind the substantially different attitude of investors towards currency risk.

Also, the difference between currency risk premiums in Russia, Brazil, India and South Africa can be explained by the difference in the exports of goods too. The following export product groups represent the highest dollar value in Russian global shipments in 2015: 'crude oil' (62.84\%), 'metals' (9.6\%), and 'chemicals' (5.23\%) products. Brazil's exports are largely made up of 'vegetables' (18.73\%), 'food products' (11.69\%) and 'minerals' (9.11\%). India's export of goods display the familiar pattern of significant proportions of 'stone and glass' (15.67\%), 'textiles and clothing' (14.06\%), 'chemicals' (12.38\%) and 'fuels' (11.87\%). South Africa's export of goods show the biggest share of total in 'metals' (12.19\%), 'minerals' (10.98\%), 'stone and glass' (17.64\%), and 'fuels' (9.73\%). So, we can explain similar estimation results in Russia and South Africa for model 3, and in Brazil and South Africa for models 1 and 2. We can also assume, based on data from table 7 that the mining industry is making a major contribution in product exports by Russia, Brazil and South Africa.

Table 7. Product Exports by Russia, Brazil, India and South Africa in 2015

\begin{tabular}{|c|c|c|c|c|c|c|c|c|}
\hline \multirow[b]{2}{*}{ Product group } & \multicolumn{2}{|c|}{ Russia } & \multicolumn{2}{|c|}{ Brazil } & \multicolumn{2}{|c|}{ India } & \multicolumn{2}{|c|}{ South Africa } \\
\hline & $\begin{array}{c}\text { US \$ } \\
\text { billion }\end{array}$ & $\begin{array}{c}\% \\
\text { of total }\end{array}$ & $\begin{array}{c}\text { US \$ } \\
\text { billion }\end{array}$ & $\begin{array}{c}\% \\
\text { of total }\end{array}$ & $\begin{array}{c}\text { US \$ } \\
\text { billion }\end{array}$ & $\begin{array}{c}\% \\
\text { of total }\end{array}$ & $\begin{array}{l}\text { US \$ } \\
\text { billion }\end{array}$ & $\begin{array}{c}\% \\
\text { of total }\end{array}$ \\
\hline Animal & 3.21 & $0.93 \%$ & 14.48 & $7.58 \%$ & 9.36 & $3.54 \%$ & 1.05 & $1.31 \%$ \\
\hline Chemicals & 17.97 & $5.23 \%$ & 9.91 & $5.19 \%$ & 32.72 & $12.38 \%$ & 5.19 & $6.46 \%$ \\
\hline Food Products & 4.15 & $1.21 \%$ & 22.34 & $11.69 \%$ & 5.67 & $2.15 \%$ & 3.50 & $4.35 \%$ \\
\hline Footwear & 0.17 & $0.05 \%$ & 1.12 & $0.59 \%$ & 3.11 & $1.18 \%$ & 0.22 & $0.28 \%$ \\
\hline Fuels & 216.10 & $62.84 \%$ & 13.75 & $7.19 \%$ & 31.39 & $11.87 \%$ & 7.81 & $9.73 \%$ \\
\hline Hides and Skins & 0.31 & $0.09 \%$ & 2.37 & $1.24 \%$ & 3.52 & $1.33 \%$ & 0.39 & $0.48 \%$ \\
\hline Mach and Elec & 12.13 & $3.53 \%$ & 15.01 & $7.85 \%$ & 21.17 & $8.01 \%$ & 7.88 & $9.82 \%$ \\
\hline Metals & 33.01 & $9.60 \%$ & 15.27 & $7.99 \%$ & 21.24 & $8.03 \%$ & 9.79 & $12.19 \%$ \\
\hline Minerals & 3.06 & $0.89 \%$ & 17.40 & $9.11 \%$ & 2.44 & $0.92 \%$ & 8.81 & $10.98 \%$ \\
\hline Miscellaneous & 14.08 & $4.09 \%$ & 5.23 & $2.73 \%$ & 7.12 & $2.69 \%$ & 1.85 & $2.30 \%$ \\
\hline Plastic or Rubber & 4.80 & $1.40 \%$ & 5.13 & $2.68 \%$ & 7.42 & $2.81 \%$ & 1.72 & $2.14 \%$ \\
\hline Stone and Glass & 8.89 & $2.59 \%$ & 4.67 & $2.45 \%$ & 41.42 & $15.67 \%$ & 14.16 & $17.64 \%$ \\
\hline Textiles and Clothing & 0.68 & $0.20 \%$ & 2.38 & $1.24 \%$ & 37.16 & $14.06 \%$ & 1.17 & $1.46 \%$ \\
\hline Transportation & 6.46 & $1.88 \%$ & 16.24 & $8.50 \%$ & 22.01 & $8.33 \%$ & 10.22 & $12.73 \%$ \\
\hline Vegetable & 8.83 & $2.57 \%$ & 35.79 & $18.73 \%$ & 16.75 & $6.34 \%$ & 4.37 & $5.45 \%$ \\
\hline Wood & 10.03 & $2.92 \%$ & 10.03 & $5.25 \%$ & 1.86 & $0.70 \%$ & 2.14 & $2.67 \%$ \\
\hline Total & 343.91 & $100.00 \%$ & 191.13 & $100.00 \%$ & 264.38 & $100.00 \%$ & 80.27 & $100.00 \%$ \\
\hline
\end{tabular}

Source: UN Comtrade and authors' own calculations.

As for the currency risk premia estimated using covariance between stock returns and currency value changes, no global picture emerges from our analysis. Such results might be interpreted as evidence of the complexity of currency risk impact on cost of equity, which represents one of the arguments in favour of exchange rate risk hedging.

\section{Conclusion}

This paper is dedicated to the estimation of currency risk premium in the stock markets of BRICS countries, (excluding China due to recent heavy market regulation). Generally, there are two channels through which currency movements affect the amount of cash flows of firms and, hence, their riskiness. The first one is indicated by the business operations of firms (export, import, producing abroad), and the second one is the value of assets and liabilities of firms. Both firms with international business operations and completely domestic firms are exposed to currency risk.

However, the exchange rate exposure of firms does not necessarily mean that currency risk is priced by investors. Generally, there are two classes of models which incorporate currency risk: CAPM-style models (mainly international CAPMs) and factor models (mainly the 
Fama-French Three Factor model or the Carhart Four Factor Model with a currency risk factor, though rarely an APT model).

In this research we tested different specifications of asset pricing models, which are based on the Fama-French Three Factor model, and extended by adding several risk factors. In the study we used a portfolio approach and the Fama-MacBeth procedure with rolling window estimation. Given the limitations of data for the emerging markets studied, we used two methods to construct a currency risk factor. The first one is based on a currency gains-to-sales ratio, which companies publish in annual financial reports, and the second one is based on the magnitude of covariance between stocks returns and currency returns.

We conclude that currency risk is indeed priced and significantly impacts the cost of equity of a company in Brazil, Russia, India and South Africa. In Russia, investors demand a higher expected return on equity from companies which report substantial negative currency gains. In Brazil, India and South Africa both positive and negative currency gains are associated with lower expected return. In this case, higher uncertainty might mean lower expected returns.

Examining the difference between companies for which returns positively or negatively covary with exchange rate fluctuations, we find that in Russia companies which are positively exposed to the depreciation of a currency (for example, exporters) pay a positive risk premium. At the same time, firms which are substantially exposed to unfavourable (for them) currency movements have lower expected returns on equity than firms which are not exposed to changes of exchange rate. In India, we find the opposite evidence: companies with exposure to unfavourable movements of currency pay a positive risk premium while firms with exposure to favourable exchange rate changes face a negative risk premium.

In Brazil, the situation is different. In the case of exposure to depreciation of currency, both companies with positive and negative exposure have to pay a risk premium to investors. The evidence from South Africa is similar. In case of South African companies we find significantly positive risk premium for exposure to depreciation of currency. So, we can identify similar estimation results in Russia and South Africa for model 3 and in Brazil and South Africa for model 1 and 2. We can also assume that the mining industry makes a major contribution in product exports by Russia, Brazil and South Africa.

Overall, we find consistent evidence in favour of the fact that currency risk is a significant factor that influences the cost of equity capital of a company. However, the exact impact of exchange rate risk on the cost of equity can be substantially different in various cases. The implied complexity of the relationship between currency risk and the cost of equity is one of the strongest arguments in favour exchange rate hedging of companies.

\section{References}

1) Global Currency Research Team. Global outlook. Currencies. Morgan Stanley Research. FX pulse. 2013. URL: https://www.morganstanley.com/ institutional/research/pdf/FXPulse_20130801.pdf

2) Worrachate A., Xie Y. Morgan Stanley's fragile five swells to troubled 10 in selloff. Bloomberg. 2015. URL: http://www.bloomberg.com/news/ articles/2015-08-16/morgan-stanley-s-fragile-fiveswells-to-troubled-10-in-selloff

3) Tales from the emerging world. Global emerging markets equity team. Morgan Stanley. 2013. URL: https://www.morganstanley.com/public/Tales_from the_Emerging_World_Fragile_Five.pdf

4) Adler M., Dumas B. Exposure to currency risk: Definition and measurement. Financial Management. 1984;13(2):41-50. DOI: 10.2307/3665446

5) Bodnar G.M., Marston R.C. A simple model of foreign exchange exposure. In: Negishi T., Ramachandran R.V., Mino K., eds. Economic theory, dynamics and markets. Heidelberg: Springer-Verlag; 2001:275-286. (Research Monographs in Japan-U.S. Business \& Economics. Vol 5).

6) Bodnar G.M., Dumas B., Marston R.C. Pass-through and exposure. The Journal of Finance. 2002;57(1):199231. DOI: $10.1111 / 1540-6261.00420$

7) Aggarwal R., Harper J.T. Foreign exchange exposure of "domestic" corporations. Journal of International Money and Finance. 2010;29(8):1619-1636. DOI: 10.1016/j.jimonfin.2010.05.003

8) Adler M., Dumas B. International portfolio choice and corporation finance: A synthesis. The Journal of Finance. 1983;38(3):925-984. DOI: 10.1111/j.15406261.1983.tb02511.x

9) Jorion P. The exchange-rate exposure of US multinationals. The Journal of Business. 1990;63(3):331-345. DOI: 10.1086/296510

10) Bartov E., Bodnar G.M. Firm valuation, earnings expectations, and the exchange-rate exposure effect. The Journal of Finance. 1994;49(5):1755-1785. DOI: $10.2307 / 2329270$

11) Doidge C., Griffin J., Williamson R. Measuring the economic importance of exchange rate exposure. Journal of Empirical Finance. 2006;13(4-5):550-576. DOI: 10.1016/j.jempfin.2005.12.003

12) Koutmos G., Martin A.D. Asymmetric exchange rate exposure: Theory and evidence. Journal of International Money and Finance. 2003;22(3):365383. DOI: 10.1016/S0261-5606(03)00012-3 
13) Aysun U., Guldi M. Exchange rate exposure: A nonparametric approach. Emerging Markets Review. 2011;12(4):321-337. DOI: 10.1016/j. ememar.2011.05.002

14) Bartram S.M. Linear and nonlinear foreign exchange rate exposures of German nonfinancial corporations. Journal of International Money and Finance. 2004;23(4):673-699. DOI: 10.1016/j. jimonfin.2004.03.002

15) Chaieb I., Mazzotta S. Unconditional and conditional exchange rate exposure. Journal of International Money and Finance. 2013;32:781-808. DOI: 10.1016/j. jimonfin.2012.07.001

16) Williamson R. Exchange rate exposure and competition: Evidence from the automotive industry. Journal of Financial Economics. 2001;59(3):441-475. DOI: $10.1016 / S 0304-405 X(00) 00093-3$

17) Francis B.B., Hasan I., Hunter D.M. Can hedging tell the full story? Reconciling differences in United States aggregate- and industry-level exchange rate risk premium. Journal of Financial Economics. 2008;90(2):169-196. DOI: 10.1016/j. jifineco.2007.10.007

18) Agyei-Ampomah S., Mazouz K., Yin S. The foreign exchange exposure of UK non-financial firms: A comparison of market-based methodologies. International Review of Financial Analysis. 2013;29:251-260. DOI: 10.1016/j.irfa.2012.05.006

19) Jorion P. The pricing of exchange rate risk in the stock market. Journal of Financial and Quantitative Analysis. 1991;26(3):363-376. DOI: DOI: $10.2307 / 2331212$

20) Muller A., Verschoor W.F.C. European foreign exchange risk exposure. European Financial Management. 2006;12(2):195-220. DOI: 10.1111/j.1354-7798.2006.00316.x

21) Koutmos G., Martin A.D. Modeling time variation and asymmetry in foreign exchange exposure. Journal of Multinational Financial Management. 2007;17(1):61-74. DOI: 10.1016/j.mulfin.2006.03.004

22) Doukas J.A., Hall P.H., Lang L.H. Exchange rate exposure at the firm and industry level. Financial Markets, Institutions \& Instruments. 2003;12(5):291346. DOI: 10.1046/j.0963-8008.2003.00001.x

23) Dominguez K.M.E., Tesar L.L. Exchange rate exposure. Journal of International Economics. 2006;68(1):188218. DOI: $10.1016 /$ j.jinteco.2005.01.002

24) Chang F.Y., Hsin C.W., Shiah-Hou S.R. A reexamination of exposure to exchange rate risk: The impact of earnings management and currency derivative usage. Journal of Banking \& Finance. 2013;37(8):3243-3257. DOI: 10.1016/j. jbankfin.2013.03.007

25) Lan L.H., Chen C.C., Chuang S.S. Exchange rate risk management: What can we learn from financial crises? Economic Modelling. 2015;45:187-192. DOI: 10.1016/j.econmod.2014.11.018

26) Jeon B.N., Zhen G., Zhu L. Exchange rate exposure: International evidence from daily firm-level data. Journal of Economic Integration. 2017;32(1):112-159. DOI: $10.11130 /$ jei.2017.32.1.112

27) He J., Ng L.K. The foreign exchange exposure of Japanese multinational corporations. The Journal of Finance. 1998;53(2):733-753. DOI: 10.1111/00221082.295575

28) Francis B.B., Hasan I., Hunter D.M., Zhu Y. Do managerial risk-taking incentives influence firm's exchange rate exposure? Journal of Corporate Finance. 2017;46:154-169. 10.1016/j.jcorpfin.2017.06.015

29) Bailey W., Chung Y.P. Exchange rate fluctuations, political risk, and stock returns: Some evidence from an emerging market. Journal of Financial and Quantitative Analysis. 1995;30(4):541-561. DOI: $10.2307 / 2331276$

30) Vassalou M. Exchange rate and foreign inflation risk premiums in global equity returns. Journal of International Money and Finance. 2000;19(3):433470. DOI: 10.1016/S0261-5606(00)00008-5

31) Dumas B., Solnik B. The world price of foreign exchange risk. The Journal of Finance. 1995;50(2):445479. DOI: $10.2307 / 2329415$

32) Krapl A., Giaccotto C. Foreign exchange risk and the term-structure of industry costs of equity. Journal of International Money and Finance. 2015;51:71-88. DOI: 10.1016/j.jimonfin.2014.11.001

33) Doukas J., Hall P.H., Lang L.H.P. The pricing of currency risk in Japan. Journal of Banking \& Finance. 1999;23(1):1-20. DOI: 10.1016/S03784266(98)00112-5

34) Azher S., Iqbal J. Pricing of foreign exchange risk and market segmentation: Evidence from Pakistan's equity market. Journal of Asian Economics. 2016;43:37-48. DOI: 10.1016/j.asieco.2016.03.001

35) Kolari J.W., Moorman T.C., Sorescu S.M. Foreign exchange risk and the cross-section of stock returns. Journal of International Money and Finance. 2008;27(7):1074-1097. DOI: 10.1016/j. jimonfin.2007.07.001 
36) Du D., Hu O. Exchange rate risk in the US stock market. Journal of International Financial Markets, Institutions and Money. 2012;22(1):137-150. DOI: 10.1016/j.intfin.2011.08.003

37) Apergis N., Artikis P., Sorros J. Asset pricing and foreign exchange risk. Research in International Business and Finance. 2011;25(3):308-328. DOI: 10.1016/j.ribaf.2011.02.005

38) Du D., Hu O. Cash flows, currency risk and the cost of capital. The Journal of Financial Research. 2014;37(2):139-158. DOI: 10.1111/jfir.12032

39) Du D., Hu O. Foreign exchange volatility and stock returns. Journal of International Financial Markets, Institutions and Money. 2012;22(5):1202-1216. DOI: 10.1016/j.intfin.2012.07.001

40) Armstrong W.J., Knif J., Kolari J.W., Pynnönen S. Exchange risk and universal returns: A test of international arbitrage pricing theory. Pacific-Basin Finance Journal. 2012;20(1):24-40. DOI: 10.1016/j. pacfin.2011.08.003

41) Fama E.F., French K.R. Common risk factors in the returns on stocks and bonds. Journal of Financial Economics. 1993;33(1):3-56. DOI: 10.1016/0304405X(93)90023-5

42) Fama E.F., MacBeth J.D. Risk, return, and equilibrium: Empirical tests. The Journal of Political Economy. 1973;81(3):607-636. DOI: 10.1086/260061
43) Dranev Y., Babushkin M. Asymmetric exchangerate exposure in BRIC countries. Higher School of Economics. Basic Research Program. Working Papers. 2014;(27). URL: https://www.hse.ru/data/201 4/02/04/1329381211/27FE2014.pdf

44) Shvandar K. V., Glazunov A. V. Analysis of the use of national currencies in settlements on foreign trade transactions. Nauchno-issledovatel'skii finansovyi institut. Finansovyi zhurnal = Financial Research Institute. Financial Journal. 2017;(4):122-135. (In Russ.).

45) Ang, A., Hodrick, R.J., Xing, Y., Zhang, X. The crosssection of volatility and expected returns. The Journal of Finance. 2006;61(1):259-299. DOI: 10.1111/j.15406261.2006.00836.x

46) Yakovlev I.A., Shvandar K. V. The use of the floating exchange rate regime in countries with transitional economies. Nauchno-issledovatel'skii finansovyi institut. Finansovyi zhurnal = Financial Research Institute. Financial Journal. 2015;(5):103-112. (In Russ.).

47) Smirnova N. A. Development of the mechanism of the ruble exchange rate in Russia. Nauchnoissledovatel'skii finansovyi institut. Finansovyi zhurnal = Financial Research Institute. Financial Journal. 2015;6:59-66. (In Russ.). 


\section{Appendix}

Table A1. Liquid companies in Russia

\begin{tabular}{|c|c|c|c|c|c|c|c|}
\hline Industry /Start year & 2009 & 2010 & 2011 & 2012 & 2013 & 2014 & 2015 \\
\hline Oil \& Gas & 13 & 15 & 15 & 15 & 16 & 14 & 11 \\
\hline Basic Materials & 24 & 33 & 31 & 33 & 28 & 29 & 32 \\
\hline Industrials & 12 & 18 & 17 & 14 & 15 & 15 & 18 \\
\hline Consumer Goods & 11 & 14 & 11 & 10 & 9 & 9 & 6 \\
\hline Health Care & 2 & 3 & 5 & 4 & 5 & 3 & 5 \\
\hline Consumer Services & 8 & 12 & 12 & 14 & 10 & 9 & 9 \\
\hline Telecommunications & 9 & 12 & 7 & 5 & 5 & 5 & 6 \\
\hline Utilities & 43 & 55 & 47 & 33 & 29 & 27 & 29 \\
\hline Technology & 1 & 3 & 1 & 1 & 1 & 1 & 1 \\
\hline Total & 123 & 165 & 146 & 129 & 118 & 112 & 117 \\
\hline
\end{tabular}

Source: Thomson Reuters Datastream authors' calculations.

Table A2. Liquid companies in Brazil

\begin{tabular}{|c|c|c|c|c|c|c|c|}
\hline Industry /Start year & 2009 & 2010 & 2011 & 2012 & 2013 & 2014 & 2015 \\
\hline Oil \& Gas & 5 & 5 & 7 & 8 & 10 & 10 & 9 \\
\hline Basic Materials & 12 & 11 & 12 & 9 & 10 & 12 & 11 \\
\hline Industrials & 16 & 13 & 23 & 21 & 20 & 23 & 22 \\
\hline Consumer Goods & 21 & 24 & 29 & 31 & 33 & 33 & 28 \\
\hline Health Care & 5 & 5 & 7 & 7 & 6 & 5 & 6 \\
\hline Consumer Services & 5 & 6 & 8 & 10 & 18 & 17 & 18 \\
\hline Telecommunications & 5 & 4 & 4 & 1 & 4 & 3 & 4 \\
\hline Utilities & 11 & 10 & 12 & 11 & 10 & 14 & 16 \\
\hline Technology & 2 & 2 & 3 & 2 & 2 & 3 & 2 \\
\hline Total & 82 & 80 & 105 & 100 & 113 & 120 & 116 \\
\hline
\end{tabular}

Source: Thomson Reuters Datastream and authors' calculations.

Table A3. Liquid companies in India

\begin{tabular}{|c|c|c|c|c|c|c|c|}
\hline Industry /Start year & 2009 & 2010 & 2011 & 2012 & 2013 & 2014 & 2015 \\
\hline Oil \& Gas & 11 & 12 & 12 & 11 & 12 & 12 & 13 \\
\hline Basic Materials & 43 & 42 & 44 & 45 & 45 & 45 & 46 \\
\hline Industrials & 75 & 78 & 80 & 81 & 82 & 81 & 81 \\
\hline Consumer Goods & 65 & 67 & 66 & 65 & 66 & 70 & 71 \\
\hline Health Care & 30 & 30 & 29 & 30 & 30 & 30 & 30 \\
\hline Consumer Services & 16 & 19 & 19 & 19 & 19 & 18 & 19 \\
\hline Telecommunications & 4 & 4 & 4 & 4 & 5 & 5 & 5 \\
\hline Utilities & 11 & 16 & 16 & 16 & 15 & 16 & 17 \\
\hline Technology & 20 & 20 & 19 & 19 & 21 & 21 & 21 \\
\hline Total & 275 & 288 & 289 & 290 & 295 & 298 & 303 \\
\hline
\end{tabular}

Source: Thomson Reuters Datastream and authors' calculations. 
Table A4. Liquid companies in South Africa

\begin{tabular}{|c|c|c|c|c|c|c|c|}
\hline Industry /Start year & 2009 & 2010 & 2011 & 2012 & 2013 & 2014 & 2015 \\
\hline Oil \& Gas & 1 & 2 & 2 & 2 & 2 & 2 & 4 \\
\hline Basic Materials & 28 & 30 & 31 & 28 & 29 & 29 & 26 \\
\hline Industrials & 41 & 45 & 42 & 41 & 44 & 45 & 44 \\
\hline Consumer Goods & 12 & 12 & 13 & 11 & 13 & 14 & 13 \\
\hline Health Care & 3 & 4 & 4 & 4 & 3 & 5 & 5 \\
\hline Consumer Services & 19 & 21 & 21 & 21 & 21 & 21 & 21 \\
\hline Telecommunications & 4 & 4 & 3 & 4 & 4 & 5 & 5 \\
\hline Utilities & 0 & 0 & 0 & 0 & 0 & 0 & 0 \\
\hline Technology & 8 & 7 & 7 & 8 & 12 & 11 & 10 \\
\hline Total & 116 & 125 & 123 & 119 & 128 & 132 & 128 \\
\hline
\end{tabular}

Source: Thomson Reuters Datastream and authors' calculations.

Table A5. Product Exports by Russia in billion US dollars

\begin{tabular}{|c|c|c|c|c|c|c|c|}
\hline Product group / year & 2009 & 2010 & 2011 & 2012 & 2013 & 2014 & 2015 \\
\hline Animal & 1.982 & 2.317 & 2.566 & 2.923 & 3.326 & 3.391 & 3.215 \\
\hline Chemicals & 11.428 & 14.957 & 20.373 & 22.865 & 21.388 & 21.251 & 17.974 \\
\hline Food Products & 2.394 & 1.833 & 2.354 & 4.139 & 4.946 & 5.186 & 4.152 \\
\hline Footwear & 0.033 & 0.029 & 0.036 & 0.113 & 0.168 & 0.236 & 0.168 \\
\hline Fuels & 190.171 & 260.668 & 346.530 & 368.853 & 372.036 & 346.119 & 216.101 \\
\hline Hides and Skins & 0.207 & 0.259 & 0.331 & 0.503 & 0.609 & 0.416 & 0.309 \\
\hline Mach and Elec & 8.200 & 7.796 & 8.635 & 12.169 & 13.843 & 14.184 & 12.134 \\
\hline Metals & 32.071 & 38.535 & 42.921 & 44.405 & 40.846 & 40.429 & 33.014 \\
\hline Minerals & 2.050 & 3.031 & 5.396 & 5.615 & 5.044 & 4.697 & 3.061 \\
\hline Miscellaneous & 32.002 & 44.416 & 57.619 & 14.926 & 15.605 & 13.912 & 14.082 \\
\hline Plastic or Rubber & 3.136 & 4.005 & 5.447 & 6.052 & 6.360 & 5.701 & 4.803 \\
\hline Stone and Glass & 1.969 & 3.292 & 4.426 & 15.059 & 15.654 & 13.136 & 8.895 \\
\hline Textiles and Clothing & 0.362 & 0.337 & 0.402 & 0.645 & 0.761 & 0.855 & 0.681 \\
\hline Transportation & 2.715 & 3.195 & 3.183 & 6.542 & 7.563 & 6.012 & 6.459 \\
\hline Vegetable & 4.908 & 3.417 & 6.427 & 9.683 & 7.972 & 10.430 & 8.826 \\
\hline Wood & 8.168 & 8.981 & 10.346 & 10.273 & 11.145 & 11.878 & 10.035 \\
\hline Total & 301.796 & 397.068 & 516.993 & 524.766 & 527.266 & 497.834 & 343.908 \\
\hline
\end{tabular}

Source: UN Comtrade and authors' calculations. 
Table A6. Product Exports by Brazil in billion US dollars

\begin{tabular}{|c|c|c|c|c|c|c|c|}
\hline Product group / year & 2009 & 2010 & 2011 & 2012 & 2013 & 2014 & 2015 \\
\hline Animal & 11.225 & 13.526 & 15.215 & 15.363 & 16.631 & 17.528 & 14.483 \\
\hline Chemicals & 8.077 & 10.222 & 12.180 & 11.498 & 11.087 & 11.431 & 9.914 \\
\hline Food Products & 22.854 & 27.057 & 31.787 & 31.226 & 30.277 & 26.013 & 22.341 \\
\hline Footwear & 1.481 & 1.653 & 1.504 & 1.292 & 1.269 & 1.244 & 1.119 \\
\hline Fuels & 13.658 & 19.844 & 26.791 & 26.469 & 17.822 & 20.650 & 13.748 \\
\hline Hides and Skins & 1.287 & 1.866 & 2.160 & 2.180 & 2.607 & 3.050 & 2.372 \\
\hline Mach and Elec & 13.326 & 16.217 & 19.225 & 18.805 & 17.491 & 16.944 & 15.010 \\
\hline Metals & 12.259 & 14.412 & 18.941 & 17.240 & 14.805 & 16.129 & 15.266 \\
\hline Minerals & 15.052 & 31.558 & 44.994 & 34.012 & 35.883 & 29.186 & 17.405 \\
\hline Miscellaneous & 4.859 & 6.024 & 7.497 & 8.191 & 7.200 & 7.211 & 5.226 \\
\hline Plastic or Rubber & 4.452 & 5.342 & 6.611 & 6.113 & 5.608 & 5.533 & 5.128 \\
\hline Stone and Glass & 3.142 & 3.954 & 4.685 & 4.957 & 5.128 & 4.754 & 4.674 \\
\hline Textiles and Clothing & 1.896 & 2.265 & 3.013 & 3.397 & 2.376 & 2.545 & 2.379 \\
\hline Transportation & 13.003 & 17.273 & 19.575 & 19.436 & 26.574 & 16.139 & 16.243 \\
\hline Vegetable & 19.699 & 21.962 & 32.709 & 33.726 & 38.014 & 37.182 & 35.792 \\
\hline Wood & 6.726 & 8.740 & 9.151 & 8.673 & 9.260 & 9.560 & 10.027 \\
\hline Total & 152.995 & 201.915 & 256.039 & 242.578 & 242.033 & 225.098 & 191.127 \\
\hline
\end{tabular}

Source: UN Comtrade and authors' calculations.

Table A7. Product Exports by India in billion US dollars

\begin{tabular}{|c|c|c|c|c|c|c|c|}
\hline Product group / year & 2009 & 2010 & 2011 & 2012 & 2013 & 2014 & 2015 \\
\hline Animal & 2.840 & 4.262 & 6.328 & 6.869 & 10.265 & 11.046 & 9.358 \\
\hline Chemicals & 17.057 & 22.121 & 27.074 & 31.046 & 34.856 & 33.389 & 32.722 \\
\hline Food Products & 3.786 & 5.303 & 7.255 & 7.525 & 8.098 & $\begin{array}{l}6.528 \\
6.0 .6\end{array}$ & 5.672 \\
\hline Footwear & 1.693 & 1.867 & 2.343 & 2.288 & 3.020 & 3.316 & 3.114 \\
\hline Fuels & 24.022 & 37.984 & 56.557 & 54.381 & 69.571 & 62.349 & 31.394 \\
\hline Hides and Skins & 1.980 & 2.237 & 3.040 & 3.111 & 3.863 & 3.914 & 3.524 \\
\hline Mach and Elec & 16.785 & 16.849 & 22.492 & 21.826 & 24.361 & 22.594 & 21.165 \\
\hline Metals & 12.391 & 21.937 & 21.199 & 22.078 & 25.476 & 25.585 & 21.239 \\
\hline Minerals & 6.854 & 8.042 & 6.518 & 4.928 & 4.426 & 3.347 & 2.444 \\
\hline Miscellaneous & 10.163 & 7.146 & 17.528 & 6.597 & 9.720 & 5.704 & 7.116 \\
\hline Plastic or Rubber & 3.579 & 5.314 & 8.065 & 7.715 & 9.273 & 8.266 & 7.422 \\
\hline Stone and Glass & 33.980 & 34.136 & 51.968 & 45.218 & 46.794 & 43.581 & 41.418 \\
\hline Textiles and Clothing & 21.913 & 27.128 & 33.374 & 32.683 & 40.191 & 38.598 & 37.162 \\
\hline Transportation & 10.612 & 15.101 & 19.766 & 18.231 & 21.729 & 25.900 & 22.014 \\
\hline Vegetable & 8.204 & 9.811 & 16.506 & 23.534 & 23.108 & 21.620 & 16.754 \\
\hline Wood & 0.908 & 1.171 & 1.472 & 1.534 & 1.859 & 1.808 & 1.862 \\
\hline Total & 176.765 & 220.408 & 301.483 & 289.565 & 336.611 & 317.545 & 264.381 \\
\hline
\end{tabular}

Source: UN Comtrade and authors' calculations. 
Table A8. Product Exports by South Africa in billion US dollars

\begin{tabular}{|c|c|c|c|c|c|c|c|}
\hline Product group / year & 2009 & 2010 & 2011 & 2012 & 2013 & 2014 & 2015 \\
\hline Animal & 0.626 & 1.058 & 1.041 & 0.974 & 0.975 & 1.114 & 1.051 \\
\hline Chemicals & 3.432 & 5.138 & 6.095 & 5.890 & 5.642 & 5.718 & 5.185 \\
\hline Food Products & 2.412 & 3.702 & 3.761 & 3.756 & 3.948 & 3.967 & 3.495 \\
\hline Footwear & 0.037 & 0.209 & 0.237 & 0.238 & 0.244 & 0.247 & 0.224 \\
\hline Fuels & 6.048 & 8.883 & 11.386 & 11.280 & 10.154 & 9.404 & 7.808 \\
\hline Hides and Skins & 0.157 & 0.248 & 0.333 & 0.322 & 0.480 & 0.441 & 0.388 \\
\hline Mach and Elec & 5.267 & 8.041 & 9.667 & 9.573 & 8.980 & 9.103 & 7.882 \\
\hline Metals & 8.808 & 13.443 & 13.903 & 12.127 & 11.631 & 11.987 & 9.786 \\
\hline Minerals & 6.145 & 10.320 & 14.913 & 13.375 & 14.159 & 12.354 & 8.814 \\
\hline Miscellaneous & 0.970 & 1.698 & 1.835 & 1.694 & 1.621 & 1.776 & 1.845 \\
\hline Plastic or Rubber & 1.050 & 1.754 & 2.118 & 2.291 & 2.105 & 2.161 & 1.718 \\
\hline Stone and Glass & 8.684 & 12.234 & 24.618 & 19.562 & 17.974 & 16.430 & 14.160 \\
\hline Textiles and Clothing & 0.575 & 1.099 & 1.318 & 1.278 & 1.293 & 1.256 & 1.172 \\
\hline Transportation & 5.453 & 8.628 & 9.547 & 9.799 & 9.069 & 9.646 & 10.217 \\
\hline Vegetable & 2.703 & 3.821 & 4.599 & 4.530 & 4.733 & 4.766 & 4.374 \\
\hline Wood & 1.498 & 2.355 & 2.586 & 2.135 & 2.056 & 2.220 & 2.144 \\
\hline Total & 53.864 & 82.631 & 107.956 & 98.825 & 95.063 & 92.590 & 80.265 \\
\hline
\end{tabular}

Source: UN Comtrade and authors' calculations. 